\title{
The immune biology of microsatellite unstable cancer
}

\author{
Magnus von Knebel-Doeberitz \\ From 16th International Charles Heidelberger Symposium on Cancer Research \\ Coimbra, Portugal. 26-28 September 2010
}

Colorectal cancers (CRC) develop through 2 major pathways of genetic instability. In contrast to the majority of CRCs, which are characterized by chromosomal instability, high-level microsatellite unstable (MSI-H) CRCs arise as a consequence of the loss of DNA mismatch repair (MMR) functions and show accumulation of insertion and deletion mutations particularly in microsatellite sequences. MSI-H occurs in about $15 \%$ of CRCs, and virtually all CRCs occurring in the context of the hereditary cancer-predisposing Lynch syndrome. These tumors are characterized by a comparably good prognosis and a low frequency of distant metastases. Because of the expression of a defined set of tumor-specific antigens, MSI-H CRCs elicit a strong local and systemic antitumoral immune response of the host and therefore use different strategies to evade the control of the immune system. At the conference we will summarize novel molecular mechanisms that at the same time drive pathogenesis, immunogenicity and immune evasion during the development and progression of MSIH CRCs. We will focus on the current knowledge about alterations in human leukocyte antigen (HLA) antigen presentation and discuss how immune evasion-while offering protection against local antitumoral immune responsesparadoxically might interfere with the ability of the tumor to form distant organ metastases.

Cite this article as: von Knebel-Doeberitz: The immune biology of microsatellite unstable cancer. BMC Proceedings 2010 4(Suppl 2):013.

Correspondence: knebel@med.uni-heidelberg.de

Department of Applied Tumor Biology, Institute of Pathology, University of Heidelberg, Heidelberg, Germany and Clinical Cooperation Unit, Applied Tumor Biology (G105), German Cancer Research Center (DKFZ), Heidelberg, Germany

Full list of author information is available at the end of the article

Submit your next manuscript to BioMed Central and take full advantage of:

- Convenient online submission

- Thorough peer review

- No space constraints or color figure charges

- Immediate publication on acceptance

- Inclusion in PubMed, CAS, Scopus and Google Scholar

- Research which is freely available for redistribution

Submit your manuscript at www.biomedcentral.com/submit
() Biomed Central 